\title{
A Mero-Plesiotype Series of Vanadates, Arsenates, and Phosphates with Blocks Based on Densely Packed Octahedral Layers as Repeating Modules
}

\author{
Olga Yakubovich $1, *(\mathbb{D})$ and Galina Kiriukhina ${ }^{1,2}$ (D) \\ 1 Department of Crystallography, Geological Faculty, Lomonosov Moscow State University, \\ 119991 Moscow, Russia; g-biralo@yandex.ru \\ 2 Institute of Experimental Mineralogy RAS, 142432 Chernogolovka, Russia \\ * Correspondence: yakubol@geol.msu.ru; Tel.: +7-903-975-91-06
}

Citation: Yakubovich, O.;

Kiriukhina, G. A Mero-Plesiotype

Series of Vanadates, Arsenates, and

Phosphates with Blocks Based on

Densely Packed Octahedral Layers as

Repeating Modules. Minerals 2021, 11,

273. https://doi.org/10.3390/

$\min 11030273$

Academic Editor: Giovanni Ferraris

Received: 29 January 2021

Accepted: 4 March 2021

Published: 7 March 2021

Publisher's Note: MDPI stays neutral with regard to jurisdictional claims in published maps and institutional affiliations.

\begin{abstract}
The family of layered vanadates, arsenates, and phosphates is discussed in terms of a modular concept. The group includes minerals vésignéite and bayldonite, and a number of synthetic analogous and modifications which are not isotypic, but their crystal structures comprise similar blocks (modules) consisting of a central octahedral layer filled by atoms of $d$ elements (Mn, Ni, $\mathrm{Cu}$, or $\mathrm{Co}$ ) and adjacent $\left[\mathrm{VO}_{4}\right],\left[\mathrm{AsO}_{4}\right]$, or $\left[\mathrm{PO}_{4}\right]$ tetrahedra. The octahedral layers are based on the close-packing of oxygen atoms. Within these layers having the same anionic substructure, the number and distribution of octahedral voids are different. In the crystal structures of compounds participating in the polysomatic series, these blocks alternate with various other structural fragments. These circumstances define the row of structurally-related vanadates, arsenates, and phosphates as a mero-plesiotype series. Most of the series members exhibit magnetic properties, representing two-dimensional antiferromagnets or frustrated magnets.
\end{abstract}

Keywords: modular structures; polysomes (series); synthetic analogues of minerals; transition metal phosphates; X-ray diffraction; antiferromagnets; frustrated magnets; kagomé lattice

\section{Introduction}

The modular approach for interpreting the crystal structures of minerals is well known. Its intensive use in modern crystal chemistry has become possible after the pioneer works of Thomson [1-3] and Veblen [4]. The modular concept operates with large segments (modules), which represent stable polyhedral complexes of definite topology and size, and can differ in structure and/or composition. Within this concept, the crystal structure can be interpreted as a derivative of diverse modules; then it is meant as a polysome. The polysomatism considers a particular crystal structure in required connection with other structures, assembled from the same modules. This method allows distinguishing series of non-isotypic, but crystal chemically-related phases, so-called polysomatic series, with structures built by fragments of the same topology taken in various combinations. The stability of repeating fragments is controlled by the energetic advantage of the associations of polyhedra forming these modules. Obviously, one can use the modular approach only in the case of several compounds (at least two) containing similar substructural segments (modules), with clearly pronounced rules for their spatial arrangement and alternation.

To expand the field of structurally-related compounds within the polysomatic series, Makovicky [5] proposed to adopt a possibility of variations both in the structure and in the chemical composition of modules still keeping their topological similarity. These advanced sequences of compounds were called mero-plesiotype series. In the framework of this concept, a "common" fragment for all of the structures shows clear variability; besides, modules of another type are dissimilar for different members of the series [6,7].

Through efforts of numerous scientific schools, this methodology has allowed the introduction of many families of inorganic compounds, including minerals, as polysomatic 
series of oxides, sulfosalts, silicates, manganates, phosphates, etc. [8-21]. Several aspects of modular analysis such as symmetrical, topological classification can be mentioned. Usually, they are all interconnected; all are presented and complement each other in the study. In addition, the polysomatic model facilitates the representation of mineral transformation and substitution reactions and also allows predicting possible topological constraints in the propagation of mineral reactions [22]. It is difficult to overestimate the heuristic potential of this approach, since the prediction of the structural state of atoms and atomic groups, the way of their interaction within the crystal, ion migration paths, and the features of chemical bonds are extremely important in the context of the targeted selection of compounds for studying their physical properties that underlie the creation of new materials.

Within a program to explore the synthesis and crystal chemistry of compounds, potentially interesting as possible battery electrodes and/or magnetic materials, we have established crystal structures of two transition and alkaline metal phases synthesized under hydrothermal conditions, namely the first vanadate carbonate, $\mathrm{K}_{2} \mathrm{Mn}_{3}\left[\mathrm{VO}_{4}\right]_{2}\left(\mathrm{CO}_{3}\right)$ [23] and the sodium nickel hydroxide phosphate, $\mathrm{Na}_{2} \mathrm{Ni}_{3}(\mathrm{OH})_{2}\left(\mathrm{PO}_{4}\right)_{2}$ [24]. A structural study of the $\mathrm{K}_{2} \mathrm{Mn}_{3}\left[\mathrm{VO}_{4}\right]_{2}\left(\mathrm{CO}_{3}\right)$ was carried out on a crystal showing [110] twinning by merohedry. [110] is a twofold axis of the lattice (point group 6/ $\mathrm{mmm}$ ) but not of the structure (point group 6/m) and can act as twinning operation. Both structures are built of similar slabs consisting of a central octahedral layer partially filled by atoms of $d$ elements $\mathrm{Mn} / \mathrm{Ni}$ and adjacent $\left[\mathrm{VO}_{4}\right]$ or $\left[\mathrm{PO}_{4}\right]$ tetrahedra. A noticed similarity of their crystal architecture completed with research on structurally-related synthetic phases and minerals allowed us to establish a new polysomatic series of vanadates, arsenates, and phosphates with densely packed octahedral layers decorated by tetrahedra, as repeating fragments.

\section{The Main Module Topology}

The core structural module upon which the whole family is built presents the block centered by an octahedral layer filled by atoms of $d$ elements $\mathrm{Mn} / \mathrm{Ni} / \mathrm{Cu} / \mathrm{Co}$ and adjacent from both sides $\left[\mathrm{VO}_{4}\right],\left[\mathrm{PO}_{4}\right]$, and $\left[\mathrm{AsO}_{4}\right]$ tetrahedra. (In all the following figures, Mn, $\mathrm{Ni}$ and $\mathrm{Cu}$ atoms are shown in pink, green, and turquoise colors, respectively; P-, As-, and V-centered tetrahedra are colored yellow, blue, and olive green). The central layer is based on a closest sphere packing of oxygen atoms. The octahedral voids within the layer may be differently populated by the cations; therefore, various arrangements of filled and empty octahedra arise. Sheets of the brucite type (the so-called trioctahedral layers) are the densest, since they have fully occupied $\mathrm{MeO}_{6}$ octahedra sharing edges. If $2 / 3$ of the voids are filled, a gibbsite sheet (dioctahedral) is formed. These two varieties of layers present essential structural fragments of phyllosilicates and clay minerals. In the crystal structures under consideration, a fraction of the empty octahedral voids inside the oxygen sphere packing can be equal to $1 / 3$ or $1 / 4$. Besides, these voids can be differently distributed within the layer, causing differences in the structure design. From both sides of the empty octahedral voids, the tetrahedral groups are attached by sharing three vertices with $\mathrm{O}$ atoms of the layer, while the apical vertex is pointing outside towards the next module that is individual for each structure, thus defining the polysomatic series as the mero-plesiotype row. The formulae of the basic blocks may be written as $\left\{\mathrm{Me}_{2}\left[\mathrm{TO}_{4}\right]_{2}\right\}$, or $\left\{\mathrm{Me}_{3}(\mathrm{OH})_{2}\left[\mathrm{TO}_{4}\right]_{2}\right\}$, according to the number of the empty octahedra in the layer.

It is worth mentioning that the crystal structures of minerals reppiaite, $\mathrm{Mn}_{5}(\mathrm{OH})_{4}\left[\mathrm{VO}_{4}\right]_{2}[25]$, cornubite, $\mathrm{Cu}_{5}(\mathrm{OH})_{4}\left[\mathrm{AsO}_{4}\right]_{2}[26]$, and their synthetic arsenate formula analogue $\mathrm{Ni}_{5}(\mathrm{OH})_{4}\left[\mathrm{AsO}_{4}\right]_{2}$ [27] are also based on the closest sphere packing of $\mathrm{O}$ atoms. In all three cases, the atoms of transition metals occupy $5 / 6$ of the octahedral voids (Figures 1 and 2). However, the way of the empty octahedra arrangement in the monoclinic reppiaite and isotypic $\mathrm{Ni}$ arsenate structures on one hand, and in the structure of triclinic cornubite on the other, are different, providing a diverse topology of their cationic substructures, as dual-width stripes of the triangular net separated by honeycombs or dual-width stepped stripes of the triangular net separated by honeycombs (Figure 3). Note that both arrangements, as well as other diagrams shown in Figure 3 may be obtained as vacancy-modified triangular 
nets. The tetrahedral groups are placed on both sides of the layer just above and under empty octahedra with the formation of the $\left\{\mathrm{Me}_{5}(\mathrm{OH})_{4}\left[\mathrm{TO}_{4}\right]_{2}\right\}$ block. In all three structures, the similar blocks are stacked together in a direction normal to the plane of the layer through oxygen-bridging contacts. The neighboring modules are semi-translationally displaced in one direction to form an $\mathrm{AA}^{\prime}$ sequence with a period value of about $9.4 \AA$ (Table 1). Accordingly, it can be concluded that these phases with the crystal structures built exclusively from basic modules, on which the polysomatic series of vanadates, arsenates, and phosphates is based, represent the archetype structures.

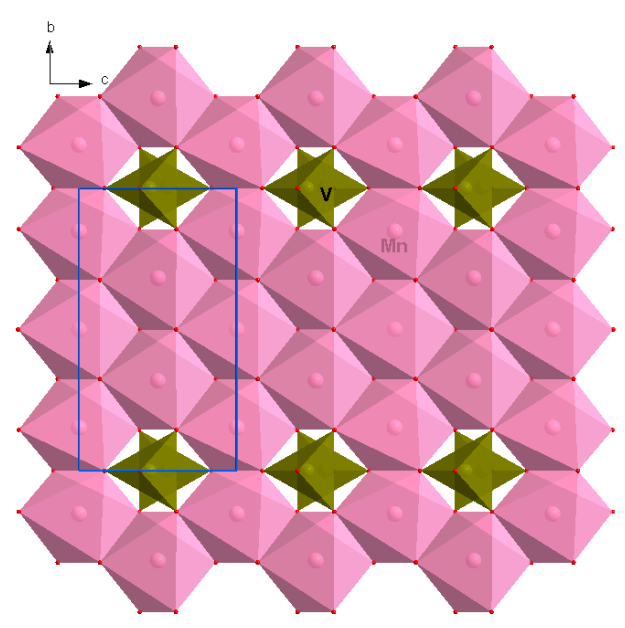

(a)

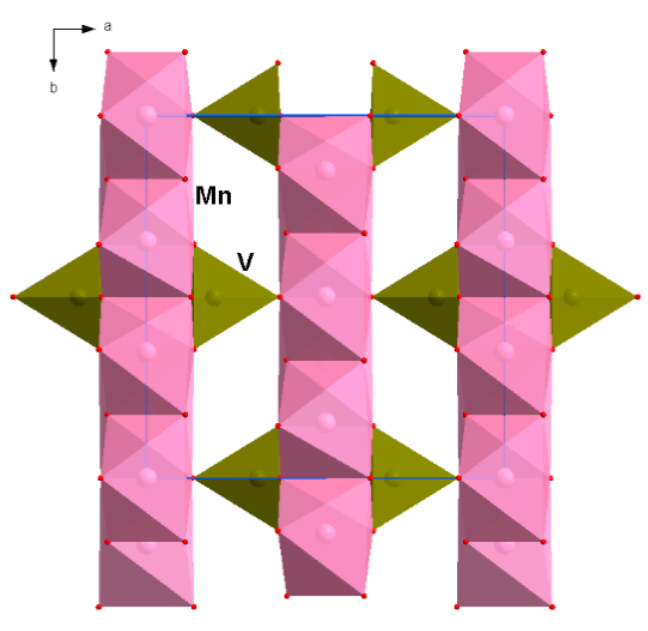

(b)

Figure 1. The crystal structure of reppiaite, $\mathrm{Mn}_{5}(\mathrm{OH})_{4}\left[\mathrm{VO}_{4}\right]_{2}$ in $y z(\mathbf{a})$ and $x y(\mathbf{b})$ projections.

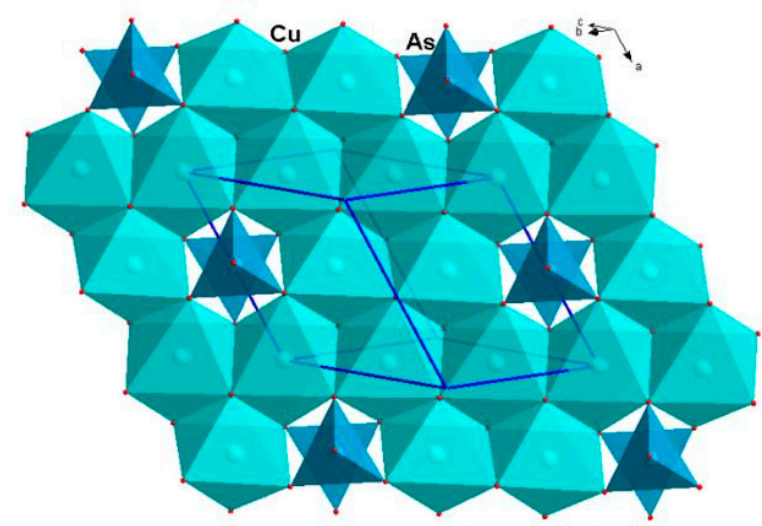

(a)

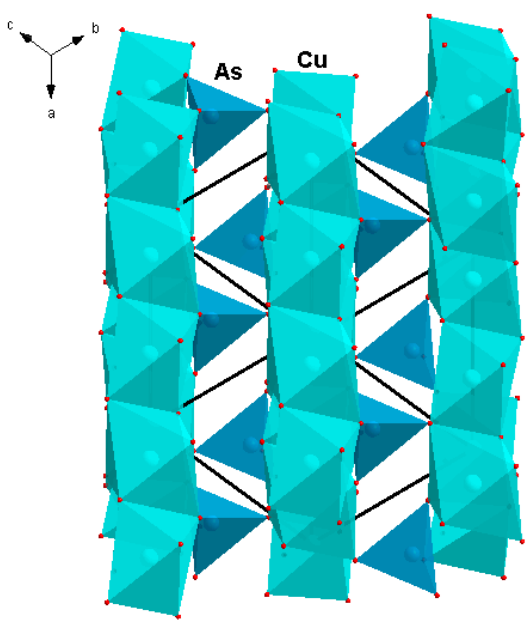

(b)

Figure 2. The crystal structure of cornubite, $\mathrm{Cu}_{5}(\mathrm{OH})_{4}\left[\mathrm{AsO}_{4}\right]_{2}$ in projections along the [011] (a) and [111] (b) directions. 


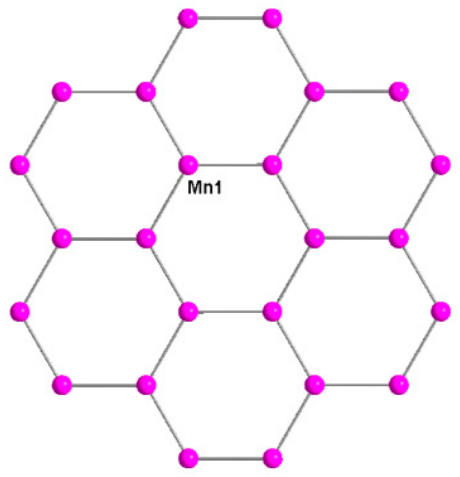

(a)

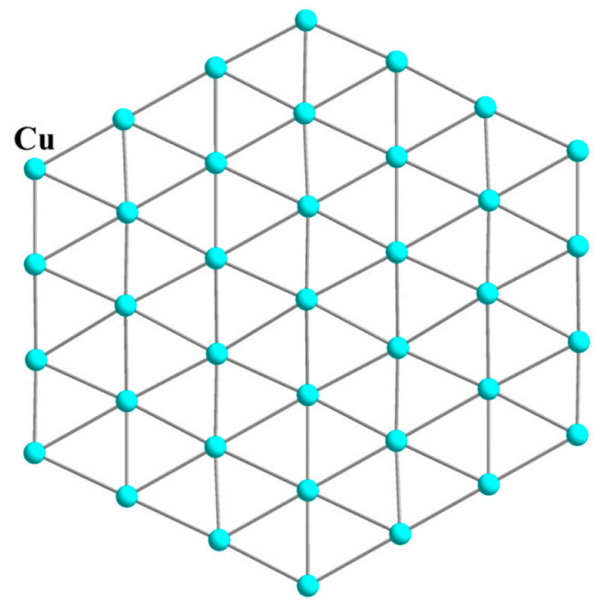

(d)

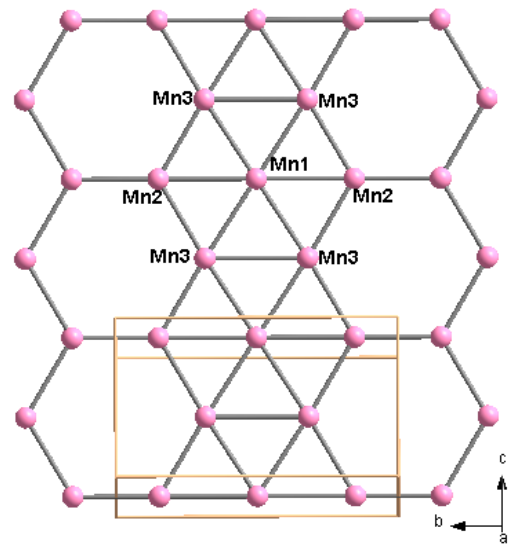

(f)

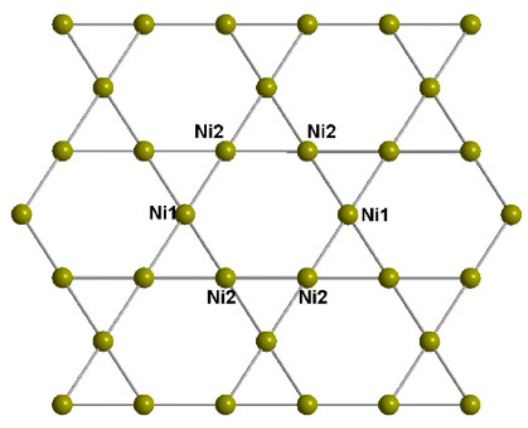

(b)

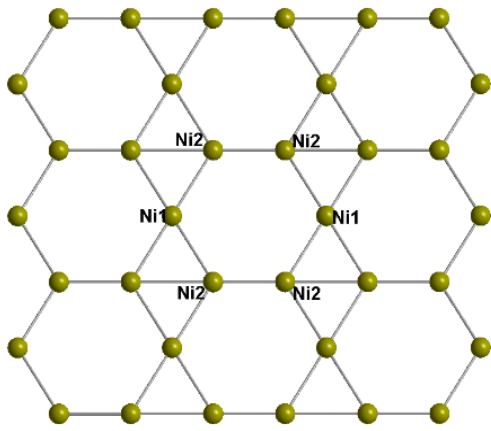

(c)

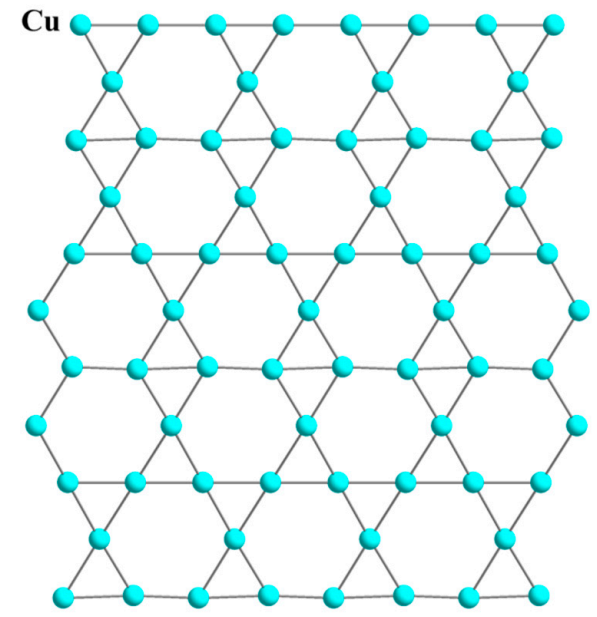

(e)

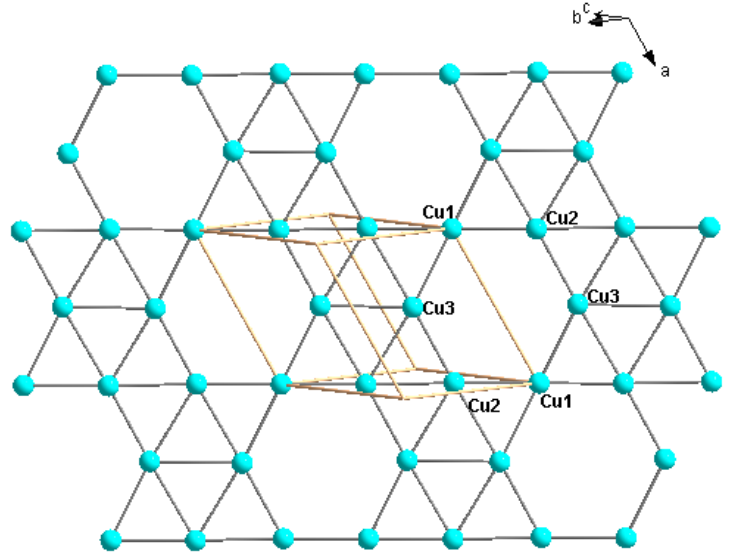

(g)

Figure 3. The topology of magnetic subsystems (cationic substructures): the honeycomb-type (or graphite-type) lattice characteristic of the gibbsite layer (the cationic substructure of the core modules in vanadate carbonates, $\mathrm{BaNi}_{2}\left[\mathrm{VO}_{4}\right]_{2}$ and other double vanadates, arsenates and phosphates) (a); The kagomé lattice (bayldonite, $\mathrm{Pb}(\mathrm{Cu}, \mathrm{Zn})_{3}(\mathrm{OH})_{2}[\mathrm{AsO}]_{2}$ and vésignéite, $\left.\mathrm{BaCu}_{3}(\mathrm{OH})_{2}\left[\mathrm{VO}_{4}\right]_{2}\right)(\mathbf{b})$; The stripes of the triangular net separated by honeycombs $\left(\mathrm{Na}_{2} \mathrm{Ni}_{3}(\mathrm{OH})_{2}\left[\mathrm{PO}_{4}\right]_{2}\right.$ and $\left.\mathrm{K}_{2} \mathrm{Mn}_{3}(\mathrm{OH})_{2}\left[\mathrm{VO}_{4}\right]_{2}\right)(\mathrm{c})$; The triangular lattice inherent for the brucite-type layers (the cationic substructure of the $\mathrm{B}$ module in $\left.\mathrm{Cu}_{13}(\mathrm{OH})_{10} \mathrm{~F}_{4}\left[\mathrm{VO}_{4}\right]_{4}\right)(\mathbf{d})$; The stepped stripes of the triangular net separated by honeycombs $\left(\mathrm{Cu}_{13}(\mathrm{OH})_{10} \mathrm{~F}_{4}\left[\mathrm{VO}_{4}\right]_{4}\right)(\mathbf{e})$; The dual-width stripes of the triangular net separated by honeycombs (reppiaite, $\left.\mathrm{Mn}_{5}(\mathrm{OH})_{4}\left[\mathrm{VO}_{4}\right]_{2}\right)(\mathbf{f})$; The dual-width stepped stripes of the triangular net separated by honeycombs (cornubite, $\left.\mathrm{Cu}_{5}(\mathrm{OH})_{4}\left[\mathrm{AsO}_{4}\right]_{2}\right)(\mathrm{g})$. 
Table 1. Mero-plesiotype series of vanadates, arsenates, and phosphates of the first-row transition metals.

\begin{tabular}{|c|c|c|c|c|}
\hline $\begin{array}{l}\text { Mineral/ } \\
\text { Synthetic Phase } \\
\text { Ref. }\end{array}$ & $\begin{array}{l}\text { Unit-cell Parameters } \\
a, b, c(\AA) \text { and } \\
\text { Angles } \alpha, \beta, \gamma\left({ }^{\circ}\right)\end{array}$ & Space Group, $V\left(\AA^{3}\right), Z$ & $\begin{array}{l}\text { Fraction of Filled Octahedra, Layer } \\
\text { Topology, Module Sequence }\end{array}$ & Magnetic Behavior \\
\hline \multicolumn{5}{|c|}{ Phases with archetype crystal structure } \\
\hline $\begin{array}{l}\mathrm{Ni}_{5}(\mathrm{OH})_{4}\left[\mathrm{AsO}_{4}\right]_{2} \\
{[27]}\end{array}$ & $\begin{array}{l}a \text { 9.291(2) } \\
b \text { 9.008(2) } \beta \text { 98.70(3) } \\
c 5.149(1)\end{array}$ & $\begin{array}{l}C 2 / m \\
426.0 \\
2\end{array}$ & $\begin{array}{l}5 / 6 \text {, dual-width triangular stripes separated } \\
\text { by honeycombs, }\left(\mathrm{AA}^{\prime}\right)\end{array}$ & $\longrightarrow$ \\
\hline $\begin{array}{l}\text { Cornubite } \mathrm{Cu}_{5}(\mathrm{OH})_{4}\left[\mathrm{AsO}_{4}\right]_{2} \\
{[26]}\end{array}$ & $\begin{array}{l}a 6.121(1) \alpha 92.93(1) \\
b 6.251(1) \beta 111.30(1) \\
c 6.790(1) \gamma 107.47(1) \\
\end{array}$ & $\begin{array}{l}P \overline{1} \\
227.1 \\
1\end{array}$ & $\begin{array}{l}5 / 6 \text {, dual-width triangular stepped stripes } \\
\text { separated by honeycombs, }\left(\mathrm{AA}^{\prime}\right)\end{array}$ & - \\
\hline \multicolumn{5}{|c|}{ Compounds forming the mero-plesiotype series } \\
\hline $\begin{array}{l}\mathrm{K}_{2} \mathrm{Mn}_{3}\left[\mathrm{VO}_{4}\right]_{2}\left(\mathrm{CO}_{3}\right) \\
{[23]}\end{array}$ & $\begin{array}{l}a 5.201(1) \\
c 22.406(3)\end{array}$ & $\begin{array}{l}P 6_{3} / m \\
524.9 \\
2\end{array}$ & $\begin{array}{l}2 / 3, \text { honeycomb } \\
\left(\text { ABA'B' }^{\prime}\right)\end{array}$ & $\begin{array}{l}\text { The honeycomb substructure orders } \\
\text { antiferromagnetically at } 85 \mathrm{~K} \text {; } \\
\text { the triangular substructure displays two ordered } \\
\text { states at } 3 \text { and } 2.2 \mathrm{~K}\end{array}$ \\
\hline $\begin{array}{l}\mathrm{K}_{2} \mathrm{Co}_{3}\left[\mathrm{VO}_{4}\right]_{2}\left(\mathrm{CO}_{3}\right) \\
{[28]}\end{array}$ & $\begin{array}{l}a \text { 5.0931(2) } \\
\text { c 22.1551(13) }\end{array}$ & $\begin{array}{l}P 6_{3} / m \\
497.7 \\
2\end{array}$ & $\begin{array}{l}2 / 3, \text { honeycomb } \\
\left(\text { ABA'B' }^{\prime}\right)\end{array}$ & Canted antiferromagnetic ordering below $8 \mathrm{~K}$ \\
\hline $\begin{array}{l}\mathrm{Rb}_{2} \mathrm{Mn}_{3}\left[\mathrm{VO}_{4}\right]_{2}\left(\mathrm{CO}_{3}\right) \\
{[28]}\end{array}$ & $\begin{array}{l}a \text { 5.2488(3) } \\
c \text { 22.7020(14) }\end{array}$ & $\begin{array}{l}P \overline{3} \\
1 c 541.6 \\
2\end{array}$ & $\begin{array}{l}2 / 3, \text { honeycomb } \\
\left(\text { ABA'B' }^{\prime}\right)\end{array}$ & $\begin{array}{l}\text { The honeycomb substructure orders } \\
\text { antiferromagnetically at } 77 \mathrm{~K} \text {; } \\
\text { the triangular substructure exhibits two transitions } \\
\text { at } 2.3 \mathrm{~K} \text { and } 1.5 \mathrm{~K}\end{array}$ \\
\hline $\begin{array}{l}\mathrm{BaNi}_{2}\left[\mathrm{VO}_{4}\right]_{2} \\
{[29]}\end{array}$ & $\begin{array}{l}a 5.028(1) \\
c 22.345(3)\end{array}$ & $\begin{array}{l}R \overline{3} \\
489.4 \\
3\end{array}$ & $\begin{array}{l}2 / 3, \text { honeycomb } \\
\left(\text { ABA'B'A"B") }^{\prime} \mathrm{B}^{\prime \prime} \mathrm{B}^{\prime}\right.\end{array}$ & $\begin{array}{l}\text { Antiferromagnetic long-range ordering close } \\
\text { to } 50 \mathrm{~K}\end{array}$ \\
\hline $\begin{array}{l}\mathrm{BaCo}_{2}\left[\mathrm{PO}_{4}\right]_{2} \\
{[30]}\end{array}$ & $\begin{array}{l}a \text { 4.8554(6) } \\
c \text { 23.2156(17) }\end{array}$ & $\begin{array}{l}R \overline{3} \\
474.0 \\
3\end{array}$ & $\begin{array}{l}2 / 3, \text { honeycomb } \\
\left(\text { ABA'B'A"B") }^{\prime}{ }^{\prime}{ }^{\prime \prime}{ }^{\prime}\right.\end{array}$ & $\begin{array}{l}\text { Competing short range magnetic orders below } \mathrm{T}_{\mathrm{N} 1} \\
\sim 6 \mathrm{~K} \text { and } \mathrm{T}_{\mathrm{N} 2} \sim 3.5 \mathrm{~K} .\end{array}$ \\
\hline $\begin{array}{l}\mathrm{BaCo}_{2}\left[\mathrm{AsO}_{4}\right]_{2} * \\
{[31]}\end{array}$ & $\begin{array}{l}a \text { 5.007(1) } \\
c \text { 23.491(5) }\end{array}$ & $\begin{array}{l}R \overline{3} \\
510.0 \\
3\end{array}$ & $\begin{array}{l}2 / 3, \text { honeycomb } \\
\left(\mathrm{ABA}^{\prime} \mathrm{B}^{\prime} \mathrm{A}^{\prime \prime} \mathrm{B}^{\prime \prime}\right)\end{array}$ & Frustrated magnet \\
\hline
\end{tabular}


Table 1. Cont.

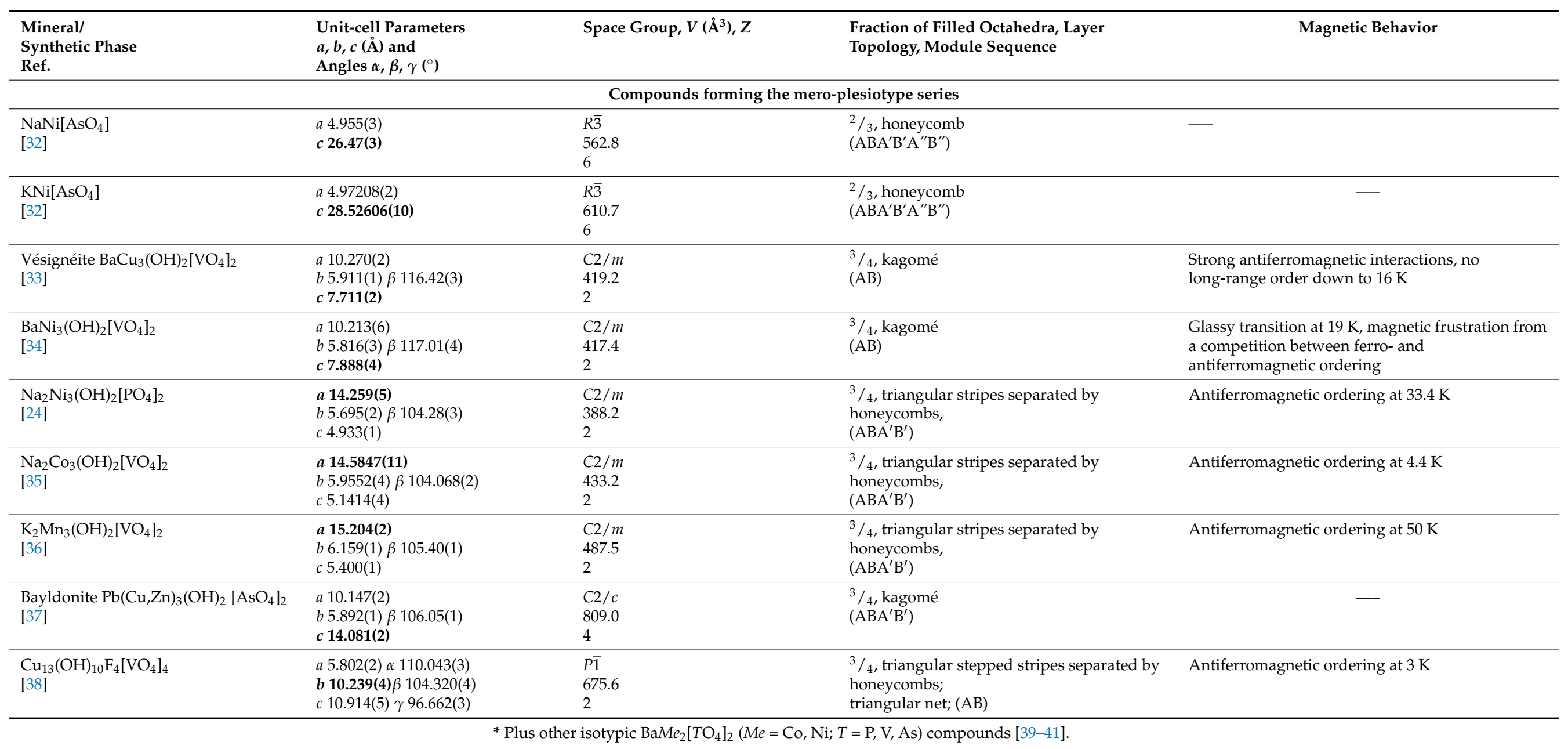




\section{The Mero-Plesiotype Series of Structurally-Related Phases}

All crystal structures of the series can be represented as an assembly of alternating twodimensional core module $\mathrm{A}$ and other slabs of diverse composition and design (Table 1).

The crystal structure of the "mineralogically probable" divanadate carbonate $\mathrm{K}_{2} \mathrm{Mn}_{3}\left[\mathrm{VO}_{4}\right]_{2}\left(\mathrm{CO}_{3}\right)$ [23] is formed by two types of modules alternating along the $c$ axis of the hexagonal unit cell (Figure 4a). Gibbsite-like layer parallel to the $a b$ plane has a honeycomb arrangement of $\mathrm{Mn}^{2+}$ cations (Figure 3a) at the centers of octahedra sharing cis and trans edges (Figure $5 \mathrm{a}$ ). The $\left[\mathrm{VO}_{4}\right]$ tetrahedra at both sides of the dioctahedral layer complete the main block to the $\mathrm{Mn}_{2}\left[\mathrm{VO}_{4}\right]_{2}$ composition and provide its linkage along the $c$ axis with the second $\left\{\mathrm{K}_{2} \mathrm{MnCO}_{3}\right\}$ module formed by $\mathrm{Mn}$-centered trigonal bipyramids, $\left[\mathrm{CO}_{3}\right]$ triangles, and $\mathrm{K}$ atoms. The $\mathrm{MnCO}_{3}$ cellular layer is topologically identical in the $a b$ plane to the kalsilite network built of Si and Al tetrahedra (Figure 5b). From both sides, these layers are attached by sheets of $\mathrm{K}$ nine-vertex polyhedra sharing vertices. Thus, the structure can be represented as an alteration of negatively charged $\left\{\mathrm{Mn}_{2}\left[\mathrm{VO}_{4}\right]_{2}\right\}^{2-}$ and positively charged $\left\{\mathrm{K}_{2} \mathrm{MnCO}_{3}\right\}^{2+}$ modules. Recently published, two novel vanadate carbonates $\mathrm{K}_{2} \mathrm{Co}_{3}\left[\mathrm{VO}_{4}\right]_{2}\left(\mathrm{CO}_{3}\right)$ and $\mathrm{Rb}_{2} \mathrm{Mn}_{3}\left[\mathrm{VO}_{4}\right]_{2}\left(\mathrm{CO}_{3}\right)$ have similar crystal structures [28]. Moreover, the $\mathrm{Mn}$ and Co containing formula analogues are isotypic, while the $\mathrm{Rb}, \mathrm{Mn}$ variety possess trigonal symmetry. The authors of [28] noted the effect of the larger size of $\mathrm{Rb}^{+}$in comparison with the size of $\mathrm{K}^{+}$on the structure transformation that occurs when the $\left[\mathrm{VO}_{4}\right]$ tetrahedra adjacent along the $c$ axis rotate around the [001] direction by $180^{\circ}$. Thus, two vanadate tetrahedra of $\left\{\mathrm{Me}_{2}\left[\mathrm{VO}_{4}\right]_{2}\right\}$ modules adjacent along the $c$ axis have the same vertex orientation "up, up" (or "down, down") in the hexagonal $\mathrm{K}_{2} \mathrm{Mn}_{3}\left[\mathrm{VO}_{4}\right]_{2}\left(\mathrm{CO}_{3}\right)$ structure, while the opposite "up, down" orientation of these tetrahedra characterizes the trigonal $\mathrm{Rb}$ formula analogue (Figure 4). Nevertheless, both compounds have similar to the $\mathrm{K}_{2} \mathrm{Mn}_{3}\left[\mathrm{VO}_{4}\right]_{2}\left(\mathrm{CO}_{3}\right)$ structural blocks, alternating $\left\{\mathrm{Me}_{2}\left[\mathrm{VO}_{4}\right]_{2}\right\}(\mathrm{A})$ and $\left\{A_{2} \mathrm{MeCO}_{3}\right\}$ (B) modules. In accordance with the action of the $6_{3}$ or $\overline{3}$ axis, the symmetrically multiplied structural $\mathrm{A}^{\prime} \mathrm{B}^{\prime}$ fragment is shifted by $1 / 2$ of the translation vector along the [001] direction. The sequence of the modules' alternation $\left(\mathrm{ABA}^{\prime} \mathrm{B}^{\prime}\right)$ corresponds to the value of the $c$ axis of the unit cell that is in the range from 22 to $23 \AA$.

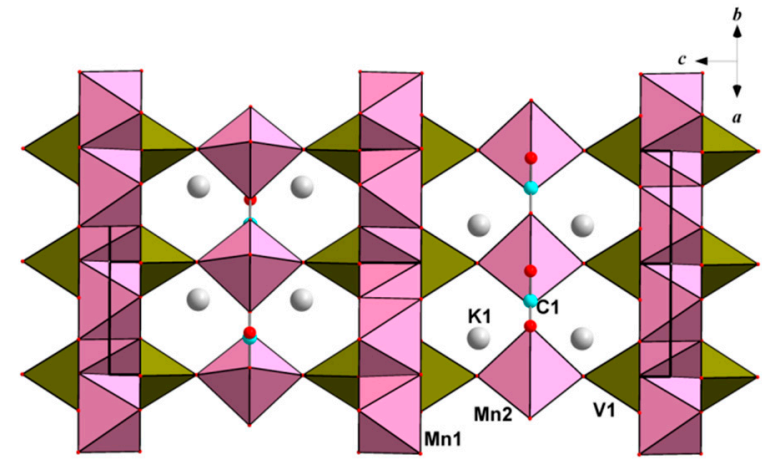

(a)

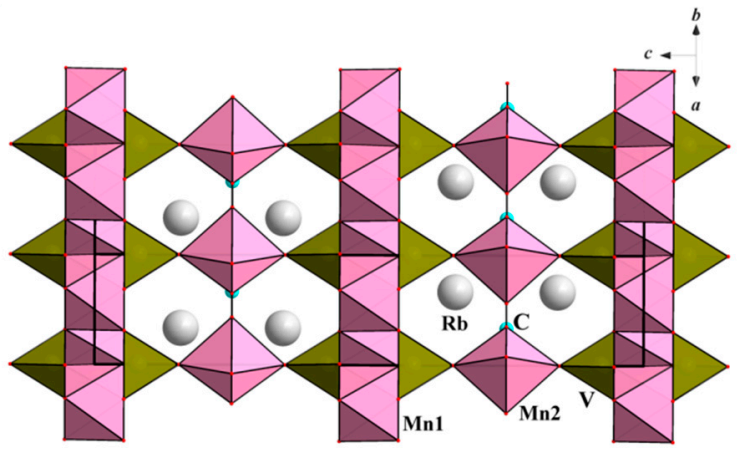

(b)

Figure 4. $\mathrm{K}_{2} \mathrm{Mn}_{3}\left[\mathrm{VO}_{4}\right]_{2}\left(\mathrm{CO}_{3}\right)(\mathbf{a})$ and $\mathrm{Rb}_{2} \mathrm{Mn}_{3}\left[\mathrm{VO}_{4}\right]_{2}\left(\mathrm{CO}_{3}\right)(\mathbf{b})$ crystal structures in the [110] projection, showing the different vertex orientation of vanadate tetrahedra. 


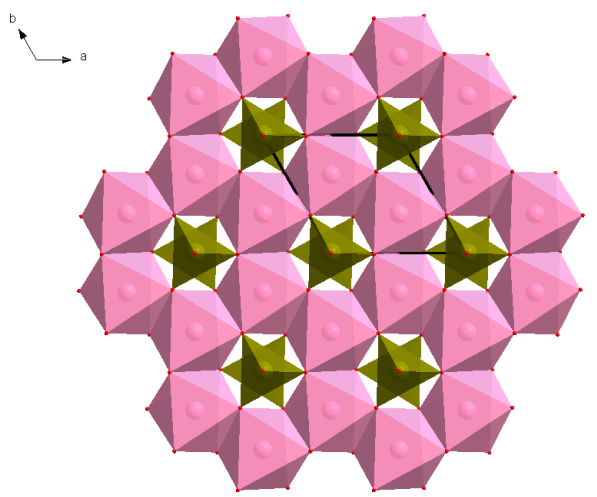

(a)

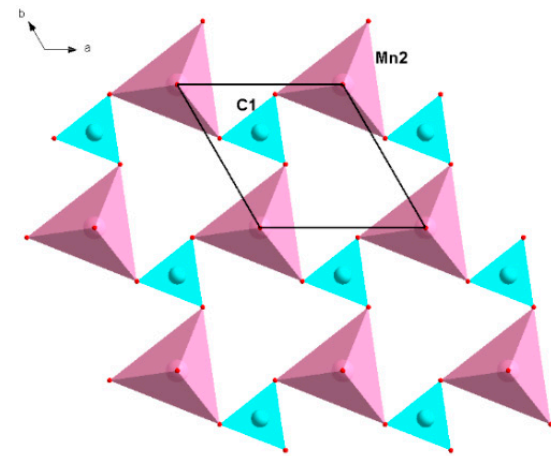

(b)

Figure 5. Gibbsite-like (a) and kalsilite-like (b) layers in the $a b$ projection of the $\mathrm{K}_{2} \mathrm{Mn}_{3}\left[\mathrm{VO}_{4}\right]_{2}\left(\mathrm{CO}_{3}\right)$ crystal structure.

The same blocks built of octahedral layers of the gibbsite-type and adjacent $\left[\mathrm{VO}_{4}\right]$ tetrahedra, form the crystal structure of $\mathrm{BaNi}_{2}\left[\mathrm{VO}_{4}\right]_{2}$ [29] with similar parameters of the trigonal unit cell, but with the $R$ Bravais lattice (Table 1 ). Due to the $R$ lattice translation, neighboring blocks of the $\mathrm{Ni}_{2}\left[\mathrm{VO}_{4}\right]_{2}$ composition are shifted in the [110] direction. Along the $c$ axis, they alternate with layers of large barium 12-vertices polyhedra sharing edges (Figure 6). In the structures of vanadate-carbonates, similar blocks alternate with the $\left\{A_{2} \mathrm{MeCO}_{3}\right\}$ modules, as shown above. The formal transformation of the structure can be restored as a result by an extraction of $\left[\mathrm{MeCO}_{3}\right]_{\infty}$ layers from the $A_{2} \mathrm{Me}_{3}\left[\mathrm{VO}_{4}\right]_{2}\left(\mathrm{CO}_{3}\right)$ crystal structure with the simultaneous exchange of $\mathrm{Me}^{2+}$ ions in octahedra for $\mathrm{Ni}^{2+}$, and one $\mathrm{Ba}^{2+}$ for two $\mathrm{K}^{+}$or two $\mathrm{Rb}^{+}$ions. Then, the $\mathrm{BaNi}_{2}\left[\mathrm{VO}_{4}\right]_{2}$ structure is obtained as a derivative of the vanadate-carbonate architecture. Translation period for the module alternation $\left(\mathrm{ABA}^{\prime} \mathrm{B}^{\prime} \mathrm{A}^{\prime \prime} \mathrm{B}^{\prime \prime}\right)$ defines the unit cell $c$ parameter equal to $22.3 \AA$ (Table 1$)$. The same structural features demonstrate isotypic cobalt phosphate $\mathrm{BaCo}_{2}\left[\mathrm{PO}_{4}\right]_{2}[30]$ and arsenate $\mathrm{BaCo}_{2}\left[\mathrm{AsO}_{4}\right]_{2}[31]$.

Let us mention here two isotypic arsenates, $\mathrm{KNi}\left[\mathrm{AsO}_{4}\right]$ and $\mathrm{NaNi}\left[\mathrm{AsO}_{4}\right]$ [32] which crystallize in the same $R \overline{3}$ space group inherent to the $\mathrm{BaNi}_{2}\left[\mathrm{VO}_{4}\right]_{2}$, but their crystal structures include twice more alkali cations between $\left\{\mathrm{Me}_{2}\left[\mathrm{TO}_{4}\right]_{2}\right\}$ modules as compared with the amount of alkali earth $\mathrm{Ba}$ atoms in the vanadate. Consequently, the increased $c$ parameters of $\mathrm{KNiAsO}_{4}$ and $\mathrm{NaNiAsO}_{4}$ to 28.53 and $26.47 \AA$ correspond to two-layer blocks of sharing edges seven-vertex K- or Na-centered polyhedra between the main modules of the arsenate structures.

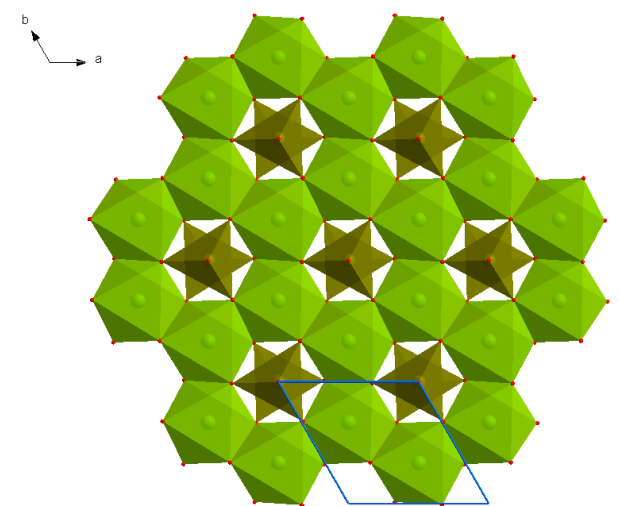

(a)

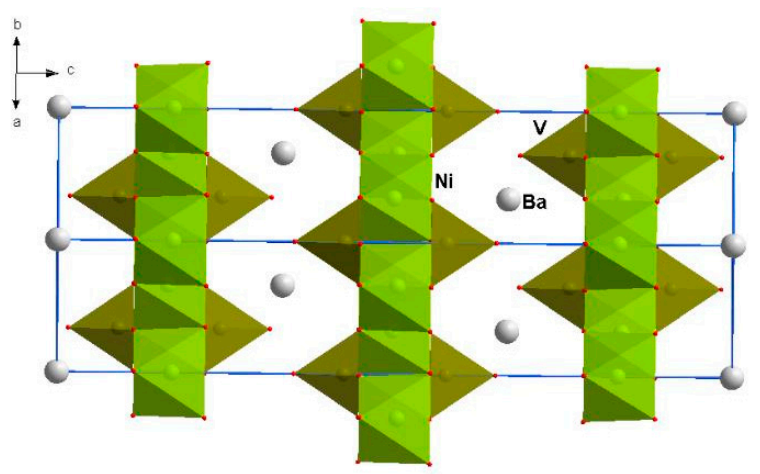

(b)

Figure 6. The $\left\{\mathrm{Ni}_{2}\left[\mathrm{VO}_{4}\right]_{2}\right\}^{2-}$ module based on a gibbsite-type layer in the crystal structure of $\mathrm{BaNi}_{2}\left[\mathrm{VO}_{4}\right]_{2}(\mathbf{a})$ and its alternation with Ba-cations in [110] projection (b). 
Synthetic phases $\mathrm{Na}_{2} \mathrm{Ni}_{3}(\mathrm{OH})_{2}\left[\mathrm{PO}_{4}\right]_{2}$ [24] and $\mathrm{K}_{2} \mathrm{Mn}_{3}(\mathrm{OH})_{2}\left[\mathrm{VO}_{4}\right]_{2}$ [36] present an example of isotypic compounds from different chemical classes. A virtual exchange of all cations (except $\left.\mathrm{H}^{+}\right)$at four symmetrically independent structural positions $\left(\mathrm{Na}^{+}, \mathrm{Ni}^{2+}\right.$, $\mathrm{Ni}^{2+}$, and $\left.\mathrm{P}^{5+}\right)$ in the $\mathrm{Na}_{2} \mathrm{Ni}_{3}(\mathrm{OH})_{2}\left[\mathrm{PO}_{4}\right]_{2}$ structure for cations in the same oxidation state of a larger radius, $\left(\mathrm{K}^{+}, \mathrm{Mn}^{2+}, \mathrm{Mn}^{2+}\right.$, and $\left.\mathrm{V}^{5+}\right)$ leads to the formation of the isostructural phase, $\mathrm{K}_{2} \mathrm{Mn}_{3}(\mathrm{OH})_{2}\left[\mathrm{VO}_{4}\right]_{2}$, of the same symmetry (space group $\mathrm{C} 2 / \mathrm{m}$ ), but with obviously increased values of the unit cell parameters and the monoclinic angle (Table 1). In both cases, the layers of edge-sharing $\mathrm{MeO}_{4}(\mathrm{OH})_{2}$ octahedra include $\frac{1}{4}$ of vacancies giving rise to the cationic substructure formed of stripes of the triangular net separated by honeycombs (Figure 3c). Distances between the modules with central layers built of $\mathrm{Ni}$ or Mn octahedra are 4.2 and $4.8 \AA$ accordingly, and depend mainly on the sizes of $\left[\mathrm{PO}_{4}\right]$ and $\left[\mathrm{VO}_{4}\right]$ tetrahedra and the hydrogen bond lengths. The naturally smaller space between neighboring $\left\{\mathrm{Ni}_{3}(\mathrm{OH})_{2}\left[\mathrm{PO}_{4}\right]_{2}\right\}$ blocks in the phosphate structure suits perfectly for being filled by $\mathrm{Na}$ atoms (Figure 7). The similar modules alternate with the layers of $\mathrm{KO}_{7}$ or $\mathrm{NaO}_{7}$ polyhedra of the same topology (Figures 7 and 8).

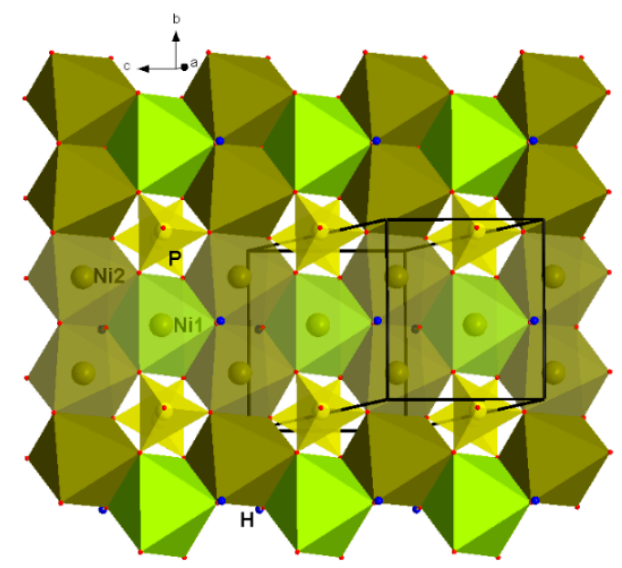

(a)

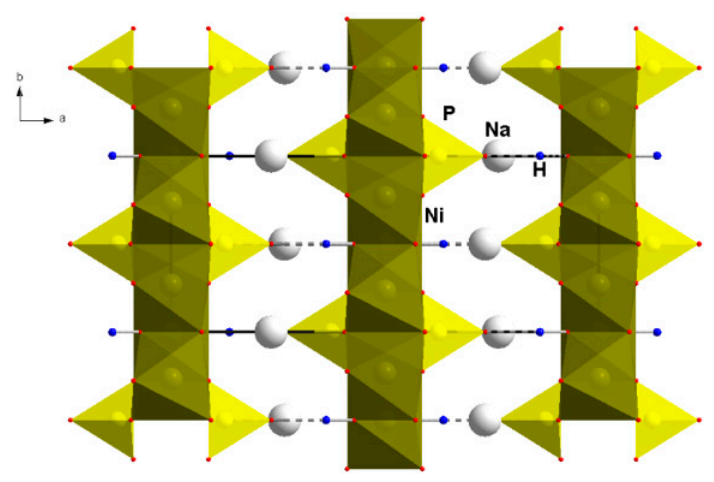

(b)

Figure 7. The crystal structure of $\mathrm{Na}_{2} \mathrm{Ni}_{3}(\mathrm{OH})_{2}\left[\mathrm{PO}_{4}\right]_{2}$ in [101] (a) and [001] (b) projections.

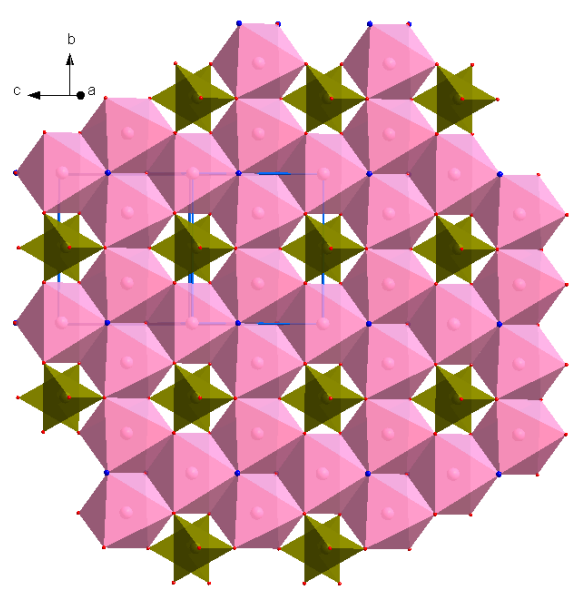

(a)

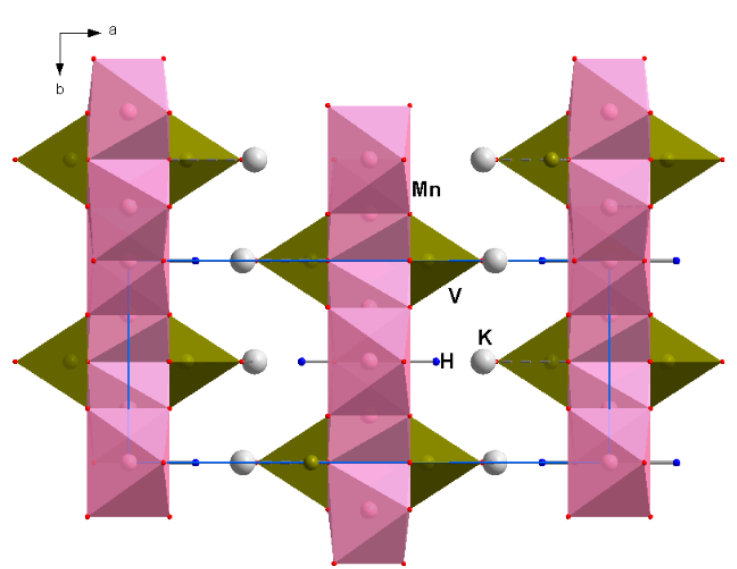

(b)

Figure 8. The crystal structure of $\mathrm{K}_{2} \mathrm{Mn}_{3}(\mathrm{OH})_{2}\left(\mathrm{VO}_{4}\right)_{2}$ in [101] (a) and [001] (b) projections.

The described above lattice (Figure 3c) stands between the honeycomb lattice (Figure 3a), characteristic of the recently discussed divanadate carbonates, and the kagomé lattice (Figure 3b), inherent in the isostructural synthetic phase $\mathrm{BaNi}_{3}(\mathrm{OH})_{2}\left[\mathrm{VO}_{4}\right]_{2}$ [34] and mineral vésignéite, $\mathrm{BaCu}_{3}(\mathrm{OH})_{2}\left[\mathrm{VO}_{4}\right]_{2}$ [33]. In the vésignéite structure, the octahedral voids of the central layers of the main modules are also filled for $\frac{3}{4}$ by the $\mathrm{Ni}$ or $\mathrm{Cu}$ atoms, 
but the distribution of the empty voids inside the octahedral layers corresponds to the regular kagomé lattice (Figure 9a). Along the [001] direction, these modules (A) alternates with layers formed by the large Ba-centered polyhedra presenting the second-type slabs $B$ (Figure $9 \mathrm{~b}$ ). The $\mathrm{AB}$ sequence of their repetition along the [001] direction defines the value of the $c$ axis close to $8 \AA$ for both compounds (Table 1 ).

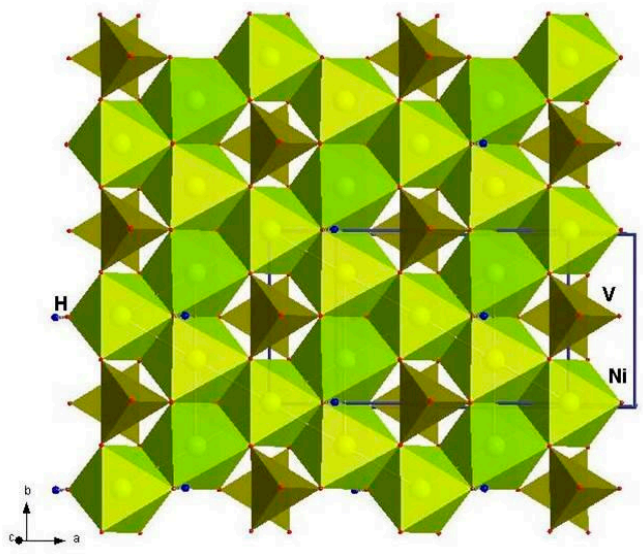

(a)

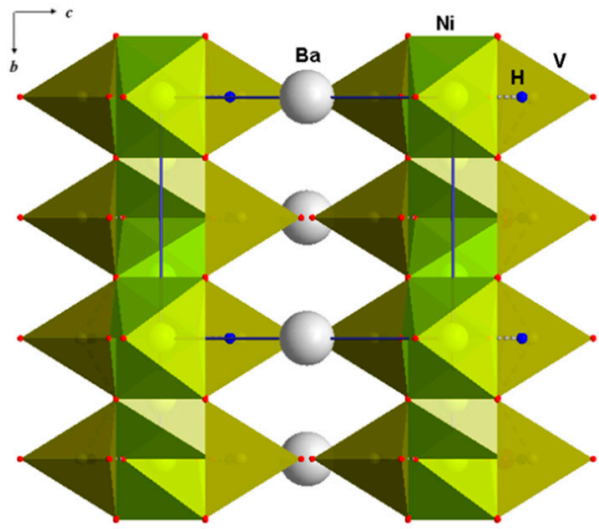

(b)

Figure 9. The crystal structure of vésignéite, $\mathrm{BaCu}_{3}(\mathrm{OH})_{2}\left[\mathrm{VO}_{4}\right]_{2}$ in projections onto the $a b(\mathbf{a})$ and $b c(\mathbf{b})$ planes.

The cationic arrangement inside the layer centering the basic block of the $\left\{(\mathrm{Cu}, \mathrm{Zn})_{3}(\mathrm{OH})_{2}\left[\mathrm{AsO}_{4}\right]_{2}\right\}$ composition in the monoclinic crystal structure of mineral bayldonite, $\mathrm{Pb}(\mathrm{Cu}, \mathrm{Zn})_{3}(\mathrm{OH})_{2}\left[\mathrm{AsO}_{4}\right]_{2}$ [37] also shows the layers with ${ }^{3} / 4$ of octahedral voids populated by the $\mathrm{Cu} / \mathrm{Zn}$ atoms. It corresponds to the same ordinary kagomé configuration as in vésignéite (Figure $3 b$ ). Along the [001] direction, these blocks (A) alternate with layers of $\mathrm{Pb}$ eight-vertex polyhedra (tetragonal antiprisms) (B) (Figure 10). However, differently to the similarly monoclinic (sp. gr. $\mathrm{C} 2 / \mathrm{m}$ ) vésignéite structure, in the present case, the modules are twice multiplied along the $c$ axis due to the symmetry (sp. gr. $C 2 / c$ ), forming the $\mathrm{ABA}^{\prime} \mathrm{B}^{\prime}$ sequence with a period of $14 \AA$.

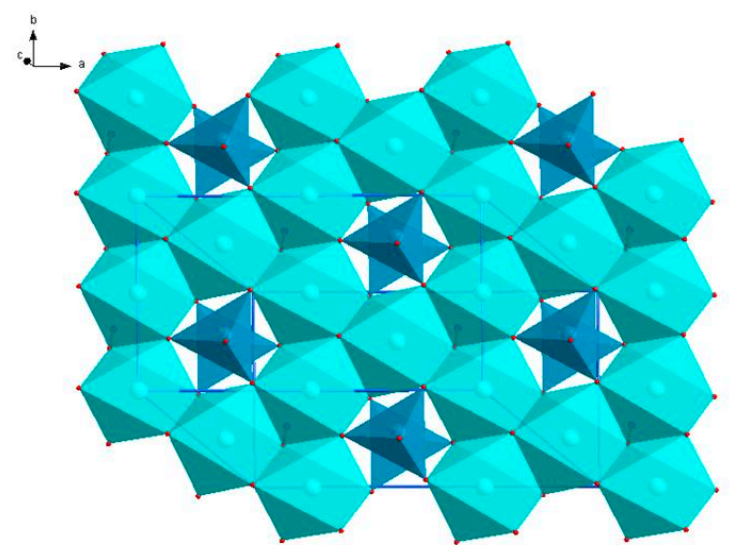

(a)

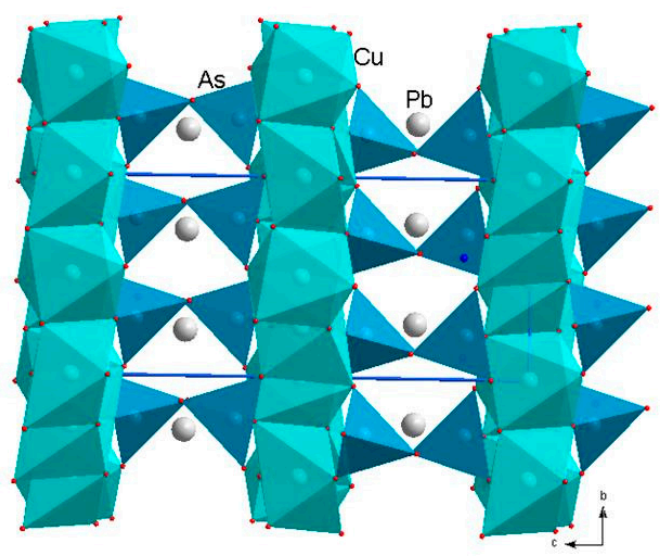

(b)

Figure 10. The crystal structure of bayldonite, $\mathrm{Pb}(\mathrm{Cu}, \mathrm{Zn})_{3}(\mathrm{OH})_{2}\left[\mathrm{AsO}_{4}\right]_{2}$ projected onto the $a b(\mathbf{a})$ and $b c(\mathbf{b})$ planes.

A unique distribution of the filled and empty octahedral voids inside the closest packing of oxygen atoms is established in the crystal structure of the synthetic oxyfluoride vanadate $\mathrm{Cu}_{13}(\mathrm{OH})_{10} \mathrm{~F}_{4}\left[\mathrm{VO}_{4}\right]_{4}$ [38]. Here, the core module A includes ${ }^{1} / 4$ of the empty octahedra, but differently to the structures discussed above, an exclusive cationic arrangement within the layer arises. It can be described as stepped stripes of the triangular net separated by honeycombs (Figure 3e). The negatively charged A modules $\left\{\mathrm{Cu}_{3}(\mathrm{OH})_{2}\left[\mathrm{VO}_{4}\right]_{2}\right\}^{2-}$ formed 
by such octahedral layers with adjacent vanadate tetrahedra, alternate along the $b$ axis with $\mathrm{B}$ fragments of the brucite-type structure with a triangular sublattice (Figure $3 \mathrm{~d}$ ). These positively charged B-modules $\left\{\mathrm{Cu}_{3.5}(\mathrm{OH})_{3} \mathrm{~F}_{2}\right\}^{2+}$ are based on the densely packed oxygen and fluorine atoms, with all octahedral voids occupied by $\mathrm{Cu}$. The $\mathrm{AB}$ repetition of the modules fixes the value near $10.2 \AA$ of the $b$ parameter (Figure 11) of the triclinic unit cell (Table 1).

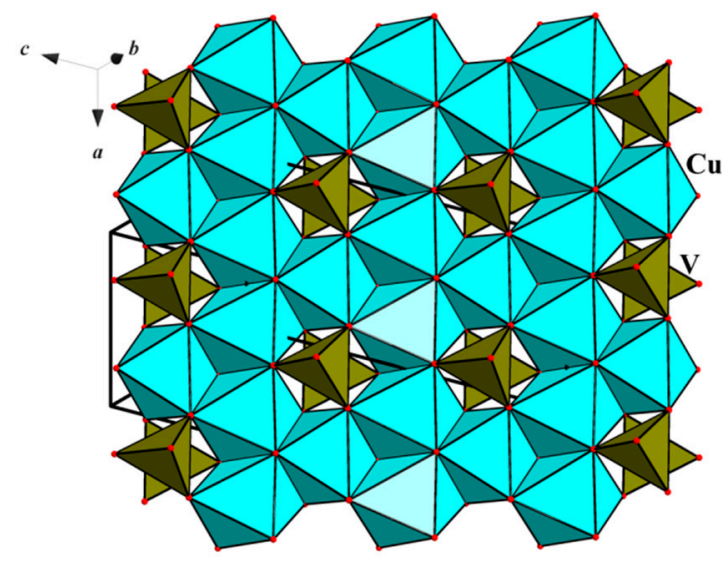

(a)

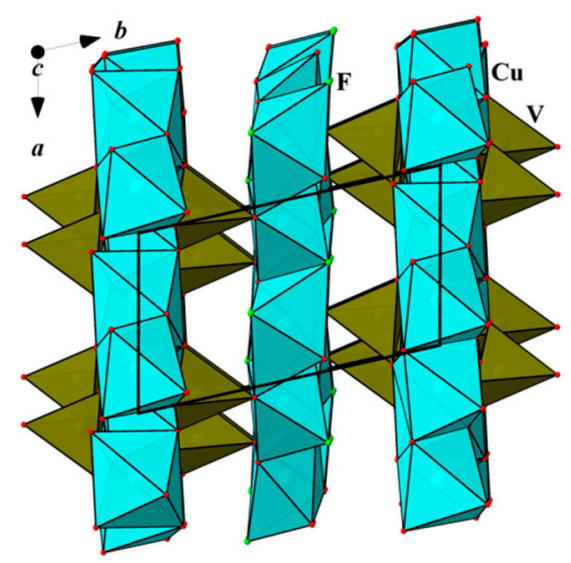

(b)

Figure 11. The $\left\{\mathrm{Cu}_{3}(\mathrm{OH})_{2}\left[\mathrm{VO}_{4}\right]_{2}\right\}^{2-}$ module in the crystal structure of $\mathrm{Cu}_{13}\left(\mathrm{VO}_{4}\right)_{4}(\mathrm{OH})_{10} \mathrm{~F}_{4}(\mathbf{a})$ and its alternation with octahedral $\left\{\mathrm{Cu}_{3.5}(\mathrm{OH})_{3} \mathrm{~F}_{2}\right\}^{2+}$ layers in [001] projection (b).

\section{Magnetic Behavior of the Series Members}

Recently, studies of quantum-spin systems have been of considerable interest. On the basis of low-dimensional magnetic systems, exotic quantum ground states of matter can be realized including gapped and gapless spin liquids [42], spin ice [43,44], spin glass, and various peculiar forms of long-range magnetic order [45-47]. If the way of the distribution of spin carriers can be described by a special lattice constructed of triangles sharing vertices or edges, such as kagomé and triangular lattices [48-50], the three-dimensional magnetic order tends to be suppressed due to spin frustration [38]. The presence of ions with an open shell $\mathrm{Mn}^{2+}, \mathrm{Ni}^{2+}, \mathrm{Co}^{2+}$, or $\mathrm{Cu}^{2+}$ inside the octahedral layers causes the appearance of two-dimensional antiferromagnetic or frustrated magnetic properties for the compounds considered in this work. Anionic tetrahedra $\left[\mathrm{PO}_{4}\right]^{3-}$, $\left[\mathrm{VO}_{4}\right]^{3-}$, or $\left[\mathrm{AsO}_{4}\right]^{3-}$ serve as ideal non-magnetic separators between transition-metal 2D planes and contribute to the octahedral environment of oxygen atoms around cations. Moreover, these units can prevent distortions of the Me-centered octahedra to preserve the planar geometry of the magnetic substructures. The way in which magnetically active ions fill octahedral voids inside the closely packed oxygen/fluorine atoms determines the type of magnetic structure (Figure 3) that inevitably contains geometric frustrations.

The kagomé lattice should provide a much stronger frustration than the simplest triangular lattice (due to the chirality degeneration), and, as a consequence, the absence of long-range magnetic order [51]. The classical kagomé lattices describe the cationic substructures of the vésignéite $\mathrm{BaCu}_{3}(\mathrm{OH})_{2}\left[\mathrm{VO}_{4}\right]_{2}$ and $\mathrm{BaNi}_{3}(\mathrm{OH})_{2}\left[\mathrm{VO}_{4}\right]_{2}$. At $53 \mathrm{~K}$, vésignéite demonstrates a strong antiferromagnetic interaction between spins of nearest-neighbors without long-range magnetic order up to $2 \mathrm{~K}$, and its ground state is assumed to be a gapless spin liquid [52]. In $\mathrm{BaNi}_{3}(\mathrm{OH})_{2}\left[\mathrm{VO}_{4}\right]_{2}$, magnetic frustration arises due to the competition between ferromagnetic and antiferromagnetic ordering, which leads to a glassy transition at $19 \mathrm{~K}$ [34]. According to [51], in the honeycomb-type substructure should be no frustration, except in the presence of next-nearest-neighbor exchange interactions. The honeycomb lattices characterize isostructural $\mathrm{BaMe}_{2}\left[\mathrm{TO}_{4}\right]_{2}(\mathrm{Me}=\mathrm{Co}, \mathrm{Ni} ; \mathrm{T}=\mathrm{P}, \mathrm{V}, \mathrm{As})$ compounds, which display quite different magnetic properties. Thus, $\mathrm{BaNi}_{2}\left[\mathrm{VO}_{4}\right]_{2}$ demonstrates the onset of antiferromagnetic long-range ordering near $50 \mathrm{~K}[29] . \mathrm{BaCo}_{2}\left[\mathrm{PO}_{4}\right]_{2}$ is a rare highly 
frustrated, quasi-2D magnetic material with the honeycomb substructure that displays competing for short-range magnetic ordering below $\mathrm{T}_{\mathrm{N} 1} \sim 6 \mathrm{~K}$ and $\mathrm{T}_{\mathrm{N} 2} \sim 3.5 \mathrm{~K}$, but resists long-range magnetic order and spin freezing [44]. The complex magnetic ordering and spin dynamics in $\mathrm{BaCo}_{2}\left[\mathrm{AsO}_{4}\right]_{2}$ has been investigated several times, but still remains an open problem. The $\mathrm{BaCo}_{2}\left[\mathrm{AsO}_{4}\right]_{2}$ frustrated magnet with the honeycomb distribution of $\mathrm{Co}$ atoms sharply ordered at $\mathrm{T} \sim 5.4 \mathrm{~K}$ with a probable formation of a helical design [53], but repeated research revealed its quasi-collinear incommensurate ground-state structure [54].

Another type of frustrated substructure, described as built from stripes of triangular nets separated by honeycombs, which is a compromise between honeycomb and kagomé lattices, should not have an antiferromagnetic order of the Néel-type, but should have geometric magnetic frustration [51]. The same lattice characterizes the isotypic crystal structures of $\mathrm{Na}_{2} \mathrm{Ni}_{3}(\mathrm{OH})_{2}\left(\mathrm{PO}_{4}\right)_{2}, \mathrm{Na}_{2} \mathrm{Co}_{3}(\mathrm{OH})_{2}\left[\mathrm{VO}_{4}\right]_{2}$, and $\mathrm{K}_{2} \mathrm{Mn}_{3}(\mathrm{OH})_{2}\left[\mathrm{VO}_{4}\right]_{2}$; they all demonstrate low-dimensional antiferromagnetic ordering of various origins. In the phosphate compound, it arises as a result of the presence and competition of ferro- and antiferromagnetic interactions [24]. Mn vanadate exhibits geometric frustration and lowdimensionality effects and spin-lattice coupling [51]. Cobalt phase shows evidence of spin-orbit coupling in $\mathrm{Co}^{2+}$ ions with antiferromagnetic ordering at 4.4.K and highly anisotropic field-dependent behavior with multiple metamagnetic transitions [35]. Dualwidth stripes of triangular net are surrounded by honeycombs in the substructure of reppiaite, $\mathrm{Mn}_{5}(\mathrm{OH})_{4}\left[\mathrm{VO}_{4}\right]_{2}$. This $2 \mathrm{D}$ magnet displays Curie-Weiss behavior above $100 \mathrm{~K}$ with significant antiferromagnetic coupling and canted antiferromagnetic order below $57 \mathrm{~K}$ [55].

In crystal structures of some compounds, magnetic cations form two types of magnetic arrangements. Thus, the complex structure of $\mathrm{Cu}_{13}(\mathrm{OH})_{10} \mathrm{~F}_{4}\left[\mathrm{VO}_{4}\right]_{4}$ is described by the triangular lattice, which alternates with a unique substructure of dual-width stripes of the triangular net separated by honeycombs. The magnetic system of $\mathrm{Cu}_{13}(\mathrm{OH})_{10} \mathrm{~F}_{4}\left[\mathrm{VO}_{4}\right]_{4}$ created in this way exhibits long-range antiferromagnetic ordering at $\sim 3 \mathrm{~K}$, a strong spin-frustration effect, and a spin-flop transition at $5 \mathrm{~T}$ [38]. Each member of the vanadatecarbonate family is also characterized by two magnetic subsystems, honeycomb- and triangular-type in their crystal structures. They all order antiferromagnetically but at different temperatures due to diverse sorts of transition cations. $\mathrm{K}_{2} \mathrm{Mn}_{3}\left[\mathrm{VO}_{4}\right]_{2}\left(\mathrm{CO}_{3}\right)$ showed a two-step formation of long-range magnetic order at low temperatures [23]. The following study showed that triangular and honeycomb magnetic layers undergo sequential magnetic ordering and act as nearly independent magnetic subsystems. The honeycomb substructure orders at about $85 \mathrm{~K}$ in a Néel-type antiferromagnetic structure, while the triangular arrangement displays two consecutive ordered states at much lower temperatures of 3 and $2.2 \mathrm{~K}$ [56]. Likewise, the $\mathrm{Rb}$-analogue $\mathrm{Rb}_{2} \mathrm{Mn}_{3}\left[\mathrm{VO}_{4}\right]_{2}\left(\mathrm{CO}_{3}\right)$ exhibits three magnetic transitions at $77 \mathrm{~K}, 2.3 \mathrm{~K}$, and $1.5 \mathrm{~K}$. At $77 \mathrm{~K}$, it orders in the honeycomb layer in a Néel-type antiferromagnetic orientation, while the lower temperature spin structure has either a collinear or a canted magnetic structure for the triangular Mn lattice [28]. $\mathrm{K}_{2} \mathrm{Co}_{3}\left(\mathrm{VO}_{4}\right)_{2} \mathrm{CO}_{3}$ displays a canted antiferromagnetic ordering below $\mathrm{T}_{\mathrm{N}}=8 \mathrm{~K}$ [28].

\section{Conclusions}

We have shown [57] that the crystal structures of the mero-plesiotype series of natural and synthetic vanadates, phosphates and arsenates with first row transition metals are formed of similar 2D modules, which alternate in one direction with other structural fragments, diverse for different members of the series. The core modules are built of a central octahedral layer filled with $d$ elements $(\mathrm{Mn}, \mathrm{Ni}, \mathrm{Cu}$, or $\mathrm{Co})$ and adjacent anionic $\left(\mathrm{VO}_{4}, \mathrm{PO}_{4}\right.$, $\mathrm{AsO}_{4}$ ) tetrahedra. The central layer is based on the closest packing of oxygen (and fluorine) atoms. Changed amounts of the octahedral voids and their varying distribution differ from one structure to another in a framework of the same anionic substructure. Seven "magnetic" topologies of the transition metal distribution within the layers have been identified: triangular, honeycomb, kagomé, and different combinations of fragments of the triangular and honeycomb lattices (Figure 3). The crystal structure constitution based 
on the same repeating modules establishes the 2D character design for all polysomes. Consequently, they all have similar translations inside the module plane equal of about $5 \AA$, while the values of the unit cell axis perpendicular to the sheet is defined by the size of the second module and the sequence of the module's alternation. The only basic type of modules with similar dimensions reproduces in one direction in the structures of minerals reppiaite $\mathrm{Mn}_{5}\left[\mathrm{VO}_{4}\right]_{2}(\mathrm{OH})_{4}$ and cornubite $\mathrm{Cu}_{5}(\mathrm{OH})_{4}\left[\mathrm{AsO}_{4}\right]_{2}$, as well as synthetic arsenate $\mathrm{Ni}_{5}(\mathrm{OH})_{4}\left[\mathrm{AsO}_{4}\right]_{2}$. Therefore, these phases with the crystal structures built exclusively from the main modules, on which the polysomatic series of vanadates, arsenates, and phosphates is based, represent the archetype structures.

When additional (B) slabs of the alkaline (or alkaline-earth) metals interrupt the basic (A) modules, a few combinations within the mero-plesiotype series are formed: $(\mathrm{AB})$ for vésignéite $\mathrm{BaCu}_{3}(\mathrm{OH})_{2}\left[\mathrm{VO}_{4}\right]_{2}$ and its $\mathrm{Ni}$-analogue $\mathrm{BaNi}_{3}(\mathrm{OH})_{2}\left[\mathrm{VO}_{4}\right]_{2}$ with approximately 7.8 A period along the modules' alternation, $\left(\mathrm{ABA}^{\prime} \mathrm{B}^{\prime}\right)$ for bayldonite $\mathrm{Pb}(\mathrm{Cu}, \mathrm{Zn})_{3}(\mathrm{OH})_{2}\left[\mathrm{AsO}_{4}\right]_{2}$, $\mathrm{Na}_{2} \mathrm{Ni}_{3}(\mathrm{OH})_{2}\left(\mathrm{PO}_{4}\right)_{2}$ and $\mathrm{K}_{2} \mathrm{Mn}_{3}(\mathrm{OH})_{2}\left[\mathrm{VO}_{4}\right]_{2}$ with about $14.5 \AA$ period, and $\left(\mathrm{ABA}^{\prime} \mathrm{B}^{\prime} \mathrm{A}^{\prime \prime} \mathrm{B}^{\prime \prime}\right)$ for $\mathrm{BaNi}_{2}\left[\mathrm{VO}_{4}\right]_{2}$ with $22.3 \AA$ translation. Another kind of supplementary slabs present the octahedral layers of brucite topology, which interconnect with the basic modules in the $\mathrm{Cu}_{13}(\mathrm{OH})_{10} \mathrm{~F}_{4}\left[\mathrm{VO}_{4}\right]_{4}$ crystal structure resulting the (AB) translation period equal to $10.2 \AA$. In the crystal structures of vanadate-carbonates $\mathrm{K}_{2} \mathrm{Mn}_{3}\left[\mathrm{VO}_{4}\right]_{2}\left(\mathrm{CO}_{3}\right), \mathrm{K}_{2} \mathrm{Co}_{3}\left[\mathrm{VO}_{4}\right]_{2}\left(\mathrm{CO}_{3}\right)$, and $\mathrm{Rb}_{2} \mathrm{Mn}_{3}\left[\mathrm{VO}_{4}\right]_{2}\left(\mathrm{CO}_{3}\right)$, two different modules alternate in a sequence $\left(\mathrm{ABA}^{\prime} \mathrm{B}^{\prime}\right)$ along the $c$ axis of about $22.4 \AA$. The main block is a core module based on the gibbsite-type octahedral layer. The second one is the block formed by the kalsilite-like sheet of $\mathrm{Mn}$ bipyramids and $\mathrm{CO}_{3}$ triangles that is sandwiched between two layers of alkaline metals.

It is important to note that the minerals and laboratory-synthesized compounds considered here exhibit magnetic properties, representing two-dimensional antiferromagnets or frustrated magnets. Obviously, their magnetic behavior is directly related to the crystal structure peculiarities. In particular, the way in which magnetically active $\mathrm{Mn}^{2+}, \mathrm{Ni}^{2+}$, $\mathrm{Co}^{2+}$, or $\mathrm{Cu}^{2+}$ ions occupy the octahedral voids between the densely packed oxygen atoms is crucial.

Author Contributions: Conceptualization, O.Y.; validation, O.Y.; investigation, O.Y. and G.K.; writing — original draft preparation, G.K.; writing—review and editing, O.Y. All authors have read and agreed to the published version of the manuscript.

Funding: The work was carried out with the support of a grant from the President of the Russian Federation for young scientists-candidates of science MK-1613.2021.1.5.

Informed Consent Statement: Not applicable.

Data Availability Statement: Not applicable.

Acknowledgments: We are much obliged to L.V. Shvanskaya for valuable recommendations and comments. We thank G. Ferraris and the reviewers for their constructive criticism, which definitely improved the article.

Conflicts of Interest: The authors declare no conflict of interest.

\section{References}

1. Thompson, J.B., Jr. Geometrical possibilities for amphibole structures: Model biopyriboles. Amer. Miner. 1970, 55, $292-293$.

2. Thompson, J.B. An Introduction to the Mineralogy and Petrology of the Biopyriboles. In Amphiboles and Other Hydrous Pyriboles-Mineralogy, Reviews in Mineralogy; Veblen, D.R., Ed.; Mineralogical Society of America: Washington, DC, USA, 1981; Volume 9A, pp. 141-188.

3. Thompson, J.B., Jr. Biopyriboles and polysomatic series. Amer. Miner. 1978, 63, 239-249.

4. Veblen, D.R. Non-Classical Pyriboles and Polysomatic Reactions in Biopyriboles. In Amphiboles and other Hydrous PyribolesMineralogy, Reviews in Mineralogy; Veblen, D.R., Ed.; Mineralogical Society of America: Washington, DC, USA, 1981; Volume 9A, pp. 189-236.

5. Makovicky, E. Modularity—Different Types and Approaches. In EMU Notes in Mineralogy, Modular Aspects of Minerals; Merlino, S., Ed.; Eötvös University Press: Budapest, Hungary, 1997; Volume 1, pp. 315-343.

6. Ferraris, G. Polysomatic Aspects of Microporous Minerals-Heterophyllosilicates, Palysepioles and Rhodesite-Related Structures. Rev. Miner. Geochem. 2005, 57, 69-104. [CrossRef] 
7. Cadoni, M.; Ferraris, G. Two new members of the rhodesite mero-plesiotype series close to delhayelite and hydrodelhayelite: Synthesis and crystal structure. Eur. J. Miner. 2009, 21, 485-493. [CrossRef]

8. Veblen, D.R. Polysomatism and polysomatic series: A review and application. Amer. Miner. 1991, 76, 801-826.

9. Veblen, D.R.; Buseck, P.R. Microstructures and reaction mechanisms in biopyriboles. Amer. Miner. 1980, 65, 599-623.

10. Welch, M.; Klinowski, J. Characterization of polysomatism in biopyriboles: Double-/triple-chain lamellar intergrowths. Phys. Chem. Miner. 1992, 18, 460-468. [CrossRef]

11. Merlino, S.; Pasero, M. Polysomatic Approach in the Crystal Chemistry Study of Minerals. In EMU Notes in Mineralogy, Modular Aspects of Minerals; Merlino, S., Ed.; Eötvös University Press: Budapest, Hungary, 1997; Volume 1, pp. $297-312$.

12. Baronnet, A.; Papp, G.; Merlino, S. Equilibrium and Kinetic Processes for Polytype and Polysome Generation. In Modular Aspects of Minerals; Mineralogical Society of America: Chantilly, VA, USA, 1997; Volume 1, pp. 119-152.

13. Drits, V.A.; Papp, G.; Merlino, S. Mixed-layer Minerals. In Modular Aspects of Minerals; Mineralogical Society of America: Chantilly, VA, USA, 1997; Volume 1, pp. 153-190.

14. Ferraris, G.; Makovicky, E.; Merlino, S. Crystallography of Modular Materials; Oxford University Press (OUP): Oxford, UK, 2008.

15. Zvyagin, B.B.; Papp, G.; Merlino, S. Modular Analysis of Crystal Structures. In Modular Aspects of Minerals; Mineralogical Society of America: Chantilly, VA, USA, 1997; Volume 1, pp. 345-372.

16. Ferraris, G.; Ivaldi, G. Structural Features of Micas. Rev. Miner. Geochem. 2002, 46, 117-153. [CrossRef]

17. Nespolo, M.; Ferraris, G.; Ďurovič, S.; Takeuchi, Y. Twins vs. modular crystal structures. Z.Kristallogr. Cryst. Mater. 2004, 219, 773-778. [CrossRef]

18. Ferraris, G. Modular structures The paradigmatic case of the heterophyllosilicates. Z. Kristallogr. Cryst. Mater. 2008, 223, 76-84. [CrossRef]

19. Yakubovich, O.V.; Dem'yanetz, L.N.; Massa, W. A New Cu, Al Fluoride Disilicate $\mathrm{CuAl}_{2} \mathrm{~F}_{2}\left(\mathrm{Si}_{2} \mathrm{O}_{7}\right)$ and its Relations to Topaz. Z. Anorg. Allg. Chem. 2000, 626, 1514-1518. [CrossRef]

20. Massa, W.; Yakubovich, O.V.; Kireev, V.V.; Mel'Nikov, O.K. Crystal structure of a new vanadate variety in the lomonosovite group: $\mathrm{Na}_{5} \mathrm{Ti}_{2} \mathrm{O}_{2}\left[\mathrm{Si}_{2} \mathrm{O}_{7}\right]\left(\mathrm{VO}_{4}\right)$. Solid State Sci. 2000, 2, 615-623. [CrossRef]

21. Yakubovich, O.V.; Massa, W.; Chukanov, N.V. Crystal structure of britvinite $\left[\mathrm{Pb}_{7}(\mathrm{OH})_{3} \mathrm{~F}\left(\mathrm{BO}_{3}\right)_{2}\left(\mathrm{CO}_{3}\right)\right]\left[\mathrm{Mg}_{4.5}\left(\mathrm{OH}_{3}\left(\mathrm{Si}_{5} \mathrm{O}_{14}\right)\right]\right.$ A new layered silicate with an original type of silicon-oxygen networks. Crystallogr. Rep. 2008, 53, 206-215. [CrossRef]

22. Bozhilov, K.N. Structures and Microstructures of Non-Classical Pyriboles. In EMU Notes in Mineralogy, Minerals at the Nanoscale; Nieto, F., Livi, K.J.T., Oberti, R., Eds.; European Mineralogical Union and the Mineralogical Society of Great Britain \& Ireland: London, UK, 2013; Volume 14, pp. 109-152.

23. Yakubovich, O.V.; Yakovleva, E.V.; Golovanov, A.N.; Volkov, A.S.; Volkova, O.S.; Zvereva, E.A.; Dimitrova, O.V.; Vasiliev, A.N The First Vanadate-Carbonate, $\mathrm{K}_{2} \mathrm{Mn}_{3}\left(\mathrm{VO}_{4}\right)_{2}\left(\mathrm{CO}_{3}\right)$ : Crystal Structure and Physical Properties. Inorg. Chem. 2013, 52, $1538-1543$. [CrossRef]

24. Yakubovich, O.; Kiriukhina, G.; Dimitrova, O.; Volkov, A.; Golovanov, A.; Volkova, O.; Zvereva, E.; Baidya, S.; Saha-Dasgupta, T.; Vasiliev, A. Crystal structure and magnetic properties of a new layered sodium nickel hydroxide phosphate, $\mathrm{Na}_{2} \mathrm{Ni}_{3}(\mathrm{OH})_{2}\left(\mathrm{PO}_{4}\right)_{2}$. Dalton Trans. 2013, 42, 14718-14725. [CrossRef] [PubMed]

25. Basso, R.; Lucchetti, G.; Zefiro, L.; Palenzona, A. Reppiaite, $\mathrm{Mn}_{5}(\mathrm{OH})_{4}\left(\mathrm{VO}_{4}\right)_{2}$, a new mineral from Val Graveglia (Northern Apennines, Italy). Z. Kristallogr. Cryst. Mater. 1992, 201, 223-234. [CrossRef]

26. Tillmanns, E.; Hofmeister, W.; Petitjean, K. Cornubite, $\mathrm{Cu}_{5}\left(\mathrm{AsO}_{4}\right)_{2}(\mathrm{OH})_{4}$, first occurrence of single crystals, mineralogical description and crystal structure. Bull. Geol. Soc. Finl. 1985, 57, 119-127. [CrossRef]

27. Barbier, J. The crystal structure of $\mathrm{Ni}_{5}\left(\mathrm{AsO}_{4}\right)_{2}(\mathrm{OH})_{4}$ and its comparison to other $\mathrm{M}_{5}\left(\mathrm{XO}_{4}\right)_{2}(\mathrm{OH})_{4}$ compounds. Eur. J. Miner. 1996, 8,77-84. [CrossRef]

28. Pellizzeri, T.M.S.; Sanjeewa, L.D.; Pellizzeri, S.; McMillen, C.D.; Garlea, V.O.; Ye, F.; Sefat, A.S.; Kolis, J.W. Single crystal neutron and magnetic measurements of $\mathrm{Rb}_{2} \mathrm{Mn}_{3}\left(\mathrm{VO}_{4}\right)_{2} \mathrm{CO}_{3}$ and $\mathrm{K}_{2} \mathrm{Co}_{3}\left(\mathrm{VO}_{4}\right)_{2} \mathrm{CO}_{3}$ with mixed honeycomb and triangular magnetic lattices. Dalton Trans. 2020, 49, 4323-4335. [CrossRef]

29. Rogado, N.; Huang, Q.; Lynn, J.W.; Ramirez, A.P.; Huse, D.; Cava, R.J. BaNi2V2O8: A two-dimensional honeycomb antiferromagnet. Phys. Rev. B 2002, 65, 144443. [CrossRef]

30. Bircsak, Z.; Harrison, W.T.A. Barium Cobalt Phosphate, $\mathrm{BaCo}_{2}\left(\mathrm{PO}_{4}\right)_{2}$. Acta Crystallogr. Sect. C Cryst. Struct. Commun. 1998, 54, 1554-1556. [CrossRef]

31. Đordević, T. $\mathrm{BaCo}_{2}\left(\mathrm{AsO}_{4}\right)_{2}$. Acta Crystallogr. Sect. E Struct. Rep. Online 2008, 64, i58-i59. [CrossRef]

32. Buckley, A.M.; Bramwell, S.T.; Day, P.; Harrison, W.T.A. The Crystal Structure of Potassium Nickel Arsenate; $\mathrm{KNiAsO}_{4}$. Z. Naturforsch. B 1988, 43, 1053-1055. [CrossRef]

33. Zhesheng, M.; Ruilin, H.; Xiaoling, Z. Redetermination of the Crystal Structure of Vesignieite. Acta Geol. Sin. 2009, 4, 145-151. [CrossRef]

34. Freedman, D.E.; Chisnell, R.; McQueen, T.M.; Lee, Y.S.; Payen, C.; Nocera, D.G. Frustrated magnetism in the S = 1 kagomé lattice $\mathrm{BaNi}_{3}(\mathrm{OH})_{2}\left(\mathrm{VO}_{4}\right)_{2}$. Chem. Commun. 2011, 48, 64-66. [CrossRef]

35. Pellizzeri, T.M.S.; Morrison, G.; McMillen, C.D.; Loye, H.Z.; Kolis, J.W. Sodium Transition Metal Vanadates from Hydrothermal Brines: Synthesis and Characterization of $\mathrm{NaMn}_{4}\left(\mathrm{VO}_{4}\right)_{3}, \mathrm{Na}_{2} \mathrm{Mn}_{3}\left(\mathrm{VO}_{4}\right)_{3}$, and $\mathrm{Na}_{2} \mathrm{Co}_{3}\left(\mathrm{VO}_{4}\right)_{2}(\mathrm{OH})_{2}$. Eur. J. Inorg. Chem. 2020, 2020, 3408-3415. [CrossRef] 
36. Liao, J.-H.; Guyomard, D.; Piffard, Y.; Tournoux, M. $\mathrm{K}_{2} \mathrm{Mn}_{3}(\mathrm{OH})_{2}\left(\mathrm{VO}_{4}\right)_{2}$, a New Two-Dimensional Potassium Manganese(II) Hydroxyvanadate. Acta Crystallogr. Sect. C Cryst. Struct. Commun. 1996, 52, 284-286. [CrossRef]

37. Ghose, S.; Wan, C. Structural chemistry of copper and zinc minerals. VI. Bayldonite, $\left.(\mathrm{Cu}, \mathrm{Zn})_{3} \mathrm{~Pb}(\mathrm{AsO})_{2}\right)_{2}(\mathrm{OH})_{2}$ : A complex layer structure. Acta Crystallogr. Sect. B Struct. Crystallogr. Cryst. Chem. 1979, 35, 819-823. [CrossRef]

38. Yang, M.; Zhang, S.-Y.; Guo, W.-B.; Tang, Y.-Y.; He, Z.-Z. Spin-frustration in a new spin-1/2 oxyfluoride system $\left(\mathrm{Cu}_{13}\left(\mathrm{VO}_{4}\right)_{4}(\mathrm{OH})_{10} \mathrm{~F}_{4}\right)$ constructed by alternatively distorted kagome-like and triangular lattices. Dalton Trans. 2015, 44, 15396-15399. [CrossRef]

39. El-Bali, B.; Bolte, M.; Boukhari, A.; Aride, J.; Taibe, M. BaNi $2\left(\mathrm{PO}_{4}\right)_{2}$. Acta Crystallogr. Sect. C Cryst. Struct. Commun. 1999, 55, 701-702. [CrossRef]

40. Régnault, L.; Henry, J.; Rossat-Mignod, J.; De Combarieu, A. Magnetic properties of the layered nickel compounds BaNi $2\left(\mathrm{PO}_{4}\right)_{2}$ and $\mathrm{BaNi}_{2}\left(\mathrm{AsO}_{4}\right)_{2}$. J. Magn. Magn. Mater. 1980, 15-18, 1021-1022. [CrossRef]

41. Zhong, R.; Chung, M.; Kong, T.; Nguyen, L.T.; Lei, S.; Cava, R.J. Field-induced spin-liquid-like state in a magnetic honeycomb lattice. Phys. Rev. B 2018, 98, 220407. [CrossRef]

42. Balents, L. Spin liquids in frustrated magnets. Nat. Cell Biol. 2010, 464, 199-208. [CrossRef] [PubMed]

43. Bramwell, S.T. Spin Ice State in Frustrated Magnetic Pyrochlore Materials. Science 2001, 294, 1495-1501. [CrossRef] [PubMed]

44. Nair, H.S.; Brown, J.M.; Coldren, E.; Hester, G.; Gelfand, M.P.; Podlesnyak, A.; Huang, Q.; Ross, K.A. Short-range order in the quantum XXZ honeycomb lattice material $\mathrm{BaCo}_{2}\left(\mathrm{PO}_{4}\right)_{2}$. Phys. Rev. B 2018, 97, 134409. [CrossRef]

45. Greedan, J.E. Geometrically frustrated magnetic materials. J. Mater. Chem. 2001, 11, 37-53. [CrossRef]

46. Moessner, R.; Ramirez, A.P. Geometrical frustration. Phys. Today 2006, 59, 24-29. [CrossRef]

47. Suzuki, N.; Matsubara, F.; Fujiki, S.; Shirakura, T. Absence of classical long-range order in an S=1/2 Heisenberg antiferromagnet on a triangular lattice. Phys. Rev. B Condens. Matter 2014, 90, 184414. [CrossRef]

48. Collins, M.F.; Petrenko, O.A. Review/Synthèse: Triangular antiferromagnets. Can. J. Phys. 1997, 75, 605-655. [CrossRef]

49. Harrison, A. First catch your hare: The design and synthesis of frustrated magnets. J. Physics: Condens. Matter 2004, 16, S553-S572. [CrossRef]

50. Pati, S.K.; Rao, C.N.R. Role of the spin magnitude of the magnetic ion in determining the frustration and low-temperature properties of kagome lattices. J. Chem. Phys. 2005, 123, 234703. [CrossRef] [PubMed]

51. Otsuka, D.; Sato, H.; Matsuo, A.; Kindo, K.; Nakamura, D.; Takeyama, S. Ultrahigh-Magnetic-Field Magnetization of MultiKagome-Strip (MKS) Lattice Spin-Frustrated Magnet $\mathrm{K}_{2} \mathrm{Mn}_{3}(\mathrm{OH})_{2}\left(\mathrm{VO}_{4}\right)_{2}$. J. Phys. Soc. Jpn. 2018, 87, 124701. [CrossRef]

52. Okamoto, Y.; Yoshida, H.; Hiroi, Z. Vesignieite $\mathrm{BaCu}_{3} \mathrm{~V}_{2} \mathrm{O}_{8}(\mathrm{OH})_{2}$ as a Candidate Spin-1/2 Kagome Antiferromagnet. J. Phys. Soc. Jpn. 2009, 78, 033701. [CrossRef]

53. Regnault, L.; Burlet, P.; Rossat-Mignod, J. Magnetic ordering in a planar X-Y model: $\mathrm{BaCo}_{2}\left(\mathrm{AsO}_{4}\right)_{2}$. Phys. B+C 1977, 86-88, 660-662. [CrossRef]

54. Regnault, L.-P.; Boullier, C.; Lorenzo, J. Polarized-neutron investigation of magnetic ordering and spin dynamics in $\mathrm{BaCo}_{2}\left(\mathrm{AsO}_{4}\right)_{2}$ frustrated honeycomb-lattice magnet. Heliyon 2018, 4, e00507. [CrossRef] [PubMed]

55. Sanjeewa, L.D.; McGuire, M.A.; McMillen, C.D.; Willett, D.; Chumanov, G.; Kolis, J.W. Honeycomb-like S = 5/2 Spin-Lattices in Manganese(II) Vanadates. Inorg. Chem. 2016, 55, 9240-9249. [CrossRef] [PubMed]

56. Garlea, V.O.; Sanjeewa, L.D.; McGuire, M.A.; Batista, C.D.; Samarakoon, A.M.; Graf, D.; Winn, B.; Ye, F.; Hoffmann, C.; Kolis, J.W. Exotic Magnetic Field-Induced Spin-Superstructures in a Mixed Honeycomb-Triangular Lattice System. Phys. Rev. X 2019, 9, 011038. [CrossRef]

57. Yakubovich, O.V.; Yakovleva, E.V.; Kirjukhina, G.V. A polysomatic series of two-dimensional vanadates, arsenates and phosphates. Acta Crystallogr. Sect. A Found. Crystallogr. 2013, 69, 125. [CrossRef] 